\title{
USE OF HISTORICAL SCIENCE OF THE RUSSIAN FEDERATION IN SUPPORTING ARMED AGGRESSION AGAINST UKRAINE
}

\author{
ВИКОРИСТАННЯ РОСІЙСЬКОЮ ФЕДЕРАЦІЄЮ \\ ІСТОРИЧНОЇ НАУКИ У ПІДТРИМАННІ ЗБРОЙНОЇ АГРЕСІЇ \\ ПРОТИ УКРАЇНИ
}

\begin{abstract}
The article deals with the use of historical (military-historical) science by the Russian Federation in the interests of the ruling political regime, for the falsification of history to substantiate aggressive foreign policy, for the impact on the historical consciousness of the population of the temporary occupied territories of Ukraine and aimed at constructing a new "identity" and maintaining occupation regime.

The purpose is to consider military-historical subjects as a tool of influence of the Russian Federation on the historical consciousness during the armed aggression against Ukraine.

Methods. To achieve this, a literature review was conducted on the subject. Also the cases of manipulation of historical facts are presented in order to achieve political goals. In addition, a comparative analysis of the impact on the addressees of political texts with metamorphic elements expressed by metaphor and political texts without metamorphic elements were used.

Conclusions. It has been found that by obeying the political regime, historical science has become a tool for the Russian authorities to solve military and political problems in order to:
\end{abstract}


- mobilize and consolidate the population of the Russian Federation in support of the foreign policy of the state;

- the ideologically "justify" the occupation of the Autonomous Republic of Crimea and the hidden armed aggression in the east of Ukraine;

- massively influence the population of the temporarily occupied territories of Ukraine using historical discourse.

\section{Анотація}

У статті розглянуто використання Російською Федерацією історичної (воєнно-історичної) науки в інтересах правлячого політичного режиму, фальсифікацію історії для обгрунтування агресивної зовнішньої політики, вплив на історичну свідомість населення тимчасово окупованих територій України, що спрямований на конструювання нової “ідентичності” та підтримування окупаційних режимів.

Мета - розглянути воєнно-історичну тематику як інструмент впливу Російської Федерації на історичну свідомість під час збройної агресії проти України.

Методи. Для досягнення зазначеної мети було проведено аналіз літератури із зазначеної проблематики; наведено випадки використання маніпуляцій історичними фактами 3 метою досягнення політичних цілей; здійснено порівняльний аналіз впливу на адресата політичних текстів з метамовними елементами, вираженими метафорою, та політичних текстів без метамовних елементів.

Висновки. 3'ясовано, що підпорядкувавшись політичному режиму, історична наука стала для російської влади інструментом вирішення воєннополітичних завдань з метою:

- мобілізації та консолідації населення Російської Федерації на підтримку зовнішньополітичного курсу держави;

- ідеологічного “обгрунтування” окупації Автономної Республіки Крим та прихованої збройної агресії на Сході України;

- масованого впливу на населення тимчасово окупованих територій України із використанням історичного дискурсу.

KEYWORDS: historical consciousness, military history, military-historical knowledge, manipulation, falsification.

Ключові слова: історична свідомість, воєнна історія, воєнно-історичні знання, маніпулювання, фальсифікація. 
Розпочата у 2014 році збройна агресія Російської Федерації проти України супроводжується масованим впливом на свідомість людей, використовуючи при цьому історичну тематику. Серед актуальних загроз національній безпеці, визначених Стратегією національної безпеки України, провідне місце належить інформаційно-психологічній війні, фальшуванню української історії, формуванню російськими засобами масової інформації викривленої картини світу. 3 огляду на це актуальності набули завдання протидії інформаційним операціям проти України, маніпуляціям суспільною свідомістю і поширенню спотвореної інформації, у тому числі на воєнно-історичну тематику.

Мета статті - розглянути воєнно-історичну тематику як інструмент впливу Російської Федерації на історичну свідомість під час збройної агресії проти України.

Педагогічні і соціальні аспекти формування історичної свідомості досліджували В. Вашкевич, А. Землянський, В. Пержун, Л. Нагорна; технології маніпуляції свідомістю були предметом наукових студій С. Кара-Мурзи, Є. Доценка, О. Бойка та ін. Питання, пов’язані з використанням історії як інструменту впливу на свідомість людей, висвітлювалися у працях вітчизняних науковців різних галузей гуманітарних наук - політології, соціології, історії.

Історична свідомість розглядається як складова суспільної свідомості, і $є$ узагальненим уявленням про людину і суспільство на конкретних історичних етапах, сукупністю ідей, поглядів, що дають змогу сприйняти минуле, а також сформувати зв'язок його із теперішнім і майбутнім. У широкому розумінні складовими іiі $€$ знання і пізнання як процес засвоєння історичних знань. Історична свідомість може формуватися на основі як систематизованої інформації (переважно через систему освіти), так і невпорядкованої (наприклад, через засоби масової інформації) [Вашкевич, 2010, с. 71]. Процес історичного пізнання кожного нового покоління здійснюється саме через спеціально організований процес, чому сприяють зусилля науковців і педагогів, які виконують фундаментальні та прикладні дослідження та забезпечують передавання знань у ході предметного вивчення розділів історичної науки, формуючи у свідомості індивіда відповідну картину світу. 
Водночас застосування різноманітних маніпулятивних технологій (замовчування, вибірковість, “перекручування”, спотворення інформації, викладення інформації у сприятливому для автора контексті, блокування “невигідноі” інформації) може ускладнювати процес пізнання, що, у свою чергу, призводить до засвоєння неповних або недостовірних знань, міфотворчості. Можливості науки, історичної зокрема, нерідко використовують в інтересах тих чи інших режимів або суспільно-політичних систем, підпорядковуючи її власним цілям [Кара-Мурза, 2005, с. 257]. При цьому авторитарні режими можуть спрямовувати пам'ять населення про минуле на вирішення економічних, соціальних, а також воєнно-політичних завдань, а історичні знання в умовах воєнно-політичного протистояння можуть стати інструментом впливу для протиборчих сторін. Таким чином на конкретне політичне замовлення можуть штучно створюватися та транслюватися через систему державних інститутів історичні міфи, що являють собою спотворену форму історичної свідомості, в якій конкретні знання й інтерпретації процесів, подій, явищ і фактів минулого передаються за допомогою образів, символів та інших емоційно-психологічних, ірраціональних компонентів, що супроводжуються поясненням тенденційного характеру.

На думку вітчизняних науковців, після розпаду Радянського Союзу історична наука Російської Федерації поступово стала частиною геополітичної стратегії держави, а історія почала використовуватися для обгрунтування агресивної зовнішньої політики. При цьому вплив на історичну свідомість здійснювався на кількох напрямах: серед західної аудиторії поширювалися міфи про “штучність” української нації і безперспективність української державності як такої, серед української - історично обумовлену єдність із російським народом, а серед громадян РФ - ідеї великодержавного шовінізму. При цьому саме воєнна історія перетворилася на фундамент російської “національної ідеї”, а апелювання до перемоги у “Великій Вітчизняній війні” або до “Великої Перемоги” стало ідеологічною опорою російської влади, що завдяки емоційному компоненту перетворилася на інструмент “зшивання" російської нації, дала державному керівництву можливість легітимації 
влади, обгрунтування ії рішень, маніпулювання свідомістю та забезпечення керованості народу, ствердження ідентичності та формування колективної пам’яті [Світова гібридна війна: український фронт, 2017, c. 71; Політика історичної пам'яті в контексті національної безпеки України, 2019, с. 36; Якубова, 2018, с. 93].

Намагання інших держав, у першу чергу колишніх радянських республік, переосмислити ті чи інші історичні події або персоналії почали розглядати у Росії як загрозу національній безпеці, “переписування” та фальсифікацію історії, що зумовлює потребу в “особливій інтерпретації” історії Росії, “консолідацію” історичної освіти тощо [Кушниренко, Ольховик, 2019, с. 134; Трушин, 2018, с. 116]. Увага вищих органів державної влади Російської Федерації до історичної науки як консолідуючого чинника знайшла своє відображення у низці нормативних документів федерального значення: прийнято Стратегію державної національної політики Російської Федерації на період до 2025 року, серед завдань якої визначено формування у підростаючого покоління почуття патріотизму, гордості за історію держави, протидію спробам її фальсифікації, перегляду результатів Другої світової війни, “применшення звитяги радянського народу у Великій вітчизняній війні 1941-1945 років"; затверджено програму “Патріотичне виховання громадян Російської Федерації на 2016-2020 роки”, одним із очікуваних результатів якої $є$ активізація і підвищення інтересу громадян РФ до вивчення історії Вітчизни, у тому числі воєнної історії, до історичного минулого держави, ії героїчних сторінок, підвищення рівня усвідомлення необхідності збереження пам'яті про значні історичні подвиги захисників Вітчизни; створено Російське військово-історичне товариство, завдання якого полягають у протидії “фальсифікаціям” історії Росії, патріотичному вихованні громадян РФ, пошуковій і меморіальній роботі, видавничій діяльності тощо [Указ Президента Российской Федерации № 1666 “Стратегия государственной национальной политики Российской Федерации на период до 2025 года” от 19.12.2012; Постановление Правительства Российской Федерации № 1493 “О государственной программе "Патриотическое воспитание граждан Российской Федерации на 2016-2020 годы” от 30.12.2015; Указ Президента Российской Фе- 
дерации № 1710 “О создании Общероссийской общественно-государственной организации “Российское военно-историческое общество” от 29.12.2012.].

Зокрема, під патронатом товариства було підготовлено та видано низку наукових і науково-популярних видань на воєнно-історичну тематику: "Історія Криму”, “Історія Новоросії, атлас “Історія Російської арміі”, “Велика війна: сто років”, “Велика Вітчизняна війна. 1941-1945”, “Герої неба”, “Атлас Перемоги” та ін. Не менш значущим напрямом роботи товариства стала участь у розробленні так званої Концепції нового навчально-методичного комплексу з історії, що містить Історико-культурний стандарт з “оцінками” та “трактуваннями” ключових історичних подій, переліком “складних питань” та короткими рекомендаціями з ідеологічно “правильного” подання матеріалу викладачами. Відстоюючи позицію, що російська історія - це історія всіх територій, країн та народів, які входили до їі складу у різні епохи, російське політичне керівництво почало науково “обгрунтовувати” спадкові права на території усіх попередніх форм “втілення” Російської імперіі: у російських виданнях зник термін “Київська Русь”, натомість з'явилося - “Древнерусское государство” як базис єдиного походження росіян, білорусів і українців; сакральне значення Херсонеса для Росії; “подарований” Україні Крим М. Хрущовим тощо [Світова гібридна війна, 2017, c. 136-137; Means of Russia hybrid warfare against Ukraine, 2017, c. 11; Гібридна війна: in verbo et in praxi, 2017, с. 208].

Окремим напрямом діяльності російських науковців після 2014 року стало дослідження, пов'язані з історією Криму. Через офіційну історичну науку почалися спроби наукового обгрунтування окупації території України і легітимації “приєднання” півострова до Російської Федерації. Висновки дисертаційних досліджень, що тією чи іншою мірою висвітлюють події так званої “крымской весны”, спрямовані переважно на виявлення закономірностей “вибору” населення Криму: культурну та ментальну єдність з Росією, регіональну ідентичність, мовну ситуацію на півострові, роль і місце проросійських організацій та рухів в АРК, особливості української внутрішньої політики після проголошення незалежності тощо [Сосновский, 2014; Старченко, 2015, Островская, 
2018]. Таким чином можна стверджувати про залежність результатів дослідницької роботи науковців від політичного замовлення і підпорядкування їх рамкам офіційної історіографії, що може бути спрямована на висвітлення одних подій і замовчування або фальсифікацію інших.

Особливо це стосується історії Другої світової війни, що у повоєнний час писалася від імені переможців. Водночас обмеження доступу громадян Російської Федерації до архівних даних, цензура, тиск та кримінальне переслідування за “... поширення завідомо неправдивих відомостей про діяльність СРСР у роки Другої світової війни” свідчить про запровадження у Росії державної “монополії” на оцінювання та інтерпретацію історичних подій [Федеральный закон № 128-Ф3 “О внесении изменений в отдельные законодательные акты Российской Федерации” от 05.05.2014; Россия против Истории. Наказание за пересмотр // Доклад Международной Агоры, 2018. - 19 с. [Электронный ресурс]. - Режим доступа: https:// agora.legal/articles/Doklad-Mezhdunarodnoi-Agory-Rossiya-protiv-IstoriiNakazanie-za-peresmotr/13], цілеспрямовану роботу, направлену на так зване “забування” як процес колективної пам'яті [Бабка, 2016, с. 42]. У першу чергу “забування” стосувалося тих чи інших подій періоду Другої світової і німецько-радянської війн, а саме:

- репресивне стирання, притаманне тоталітарним режимам (наприклад, відносини Радянського СоюзуіНімеччининапередодні та на початку Другої світової війни, невиправдано великі втрати серед особового складу радянських військ, доцільність рішень радянського військово-політичного керівництва, репресивна політика щодо громадян Радянського Союзу тощо);

- забування як принижене мовчання, коли спогади суперечать цінностям та загальноприйнятим моделям поведінки (наприклад, колабораціонізм, зрада військовій присязі серед особового складу радянських військ чи злочини проти мирного населення, складні соціально-побутові умови у воєнний та повоєнний час тощо);

- забування як складова частина формування нової ідентичності (“ми - спадкоємці Перемоги”, применшення ролі та внеску країнсоюзників, інших народів, у тому числі українського, у перемогу Антигітлерівської коаліції тощо). 
Зміцнивши авторитарний режим влади та посиливши воєнний потенціал країни, РФ почала претендувати на статус провідного центру впливу на розвиток міжнародних відносин. Російська історична (воєнно-історична)наукатакожпоступовопідпорядкувалася завданням розбудови авторитарного режиму. Водночас радянське/російське “бачення" історії колишніх республік СРСР державне керівництво Росії намагалося насаджувати і на пострадянському просторі. Стереотипи, затверджені радянською та сучасною російською історіографією, були широко застосовані під час реалізації в Україні так званої “русской весны” у 2014 році. Апелюючи до нібито “єдиної” історії, культури та мови населення Криму, Донбасу і Росії, поширювалися історичні міфологеми про: “історію Криму як перманентний подвиг російського народу”, Севастополь - “місто російської слави”; Донбас як частину "русского мира", зосередивши увагу на "Новоросії" як своєрідному утворенні часів Російської імперії; культурну та ментальну відмінність східних і західних регіонів України (“УПА - гітлерівські посіпаки", “нюрнберзький трибунал засудив українських націоналістів”) [Війна і міф. Невідома Друга світова, 2016, с. 86, 156, 186, 211].

У подальшому інформаційне супроводження збройної агресії проти України на 70\% складала саме воєнно-історична тематика, перш за все з історії Другої світової війни. Зокрема, нового значення і широкого вжитку набули радянські пропагандистські штампи воєнного і повоєнного періодів: “фашисти”, “нацисти”, “карателі”, “бандерівці”, “каральна операція” відносно населення України і діяльності військово-політичного керівництва та представників сектору безпеки і оборони держави.

Фальсифікація історії через освітню і культурну сфери стала однією з основних стратегій впливу на свідомість населення і на тимчасово окупованих Російською Федерацією територіях України - Автономній Республіці Крим та окремих районах Донецької і Луганської областей. Зокрема, у посібниках із історії, розроблених для "республіканських" загальноосвітніх навчальних закладів, збройний конфлікт на Донбасі порівнюється із “Великою Вітчизняною війною” 1941-1945 років, а незаконні збройні формування і російські окупаційні війська (сили) - “... прості шахтарі, ... вчителі і лікарі...”, які “... взяли в руки зброю, 
щоб захистити свою Вітчизну” [Историческое краеведение: Введение в историю Донецкого края, 2019, с. 211]. Крім того, школярам пропонують для виконання завдання: провести історичну паралель між подіями на висоті Савур-Могила в роки “Великої Вітчизняної війни” і в наші дні, написати історичне есе на тему “ДНР і ДКСР: історичні паралелі” тощо [Историческое краеведение. Страницы истории Донбасса: новейшая и современная история (с 1939 года до современности), 2019, c. 97, 115].

Російські ідеологи сконцентрували увагу на конструюванні “самоідентифікації” населення окупованих територій на Сході України через нібито історичну спадкоємність “квазіреспублік” від “Донецько-Криворізької республіки” - утворення початку XX ст. (зокрема, наголошуючи, що другою столицею “республіки” у 1918 р. був Луганськ, а умовою входження й перебування іiі у складі радянської України нібито було обов’язкове перебування останньої в єдиній союзній державі з РРФСР) [Аналітична доповідь до Щорічного Послання Президента України до Верховної Ради України, 2018, с. 102-103]. “Легітимацію” цієї спадкоємності було здійснено 6 лютого 2015 року із прийняттям “урядом ДНР” так званого Меморандуму “Об основах государственного строительства, политической и исторической преемственности”. Іншим напрямом роботи у квазіреспубліках стало “патріотичне виховання” молоді через формування антиукраїнських переконань і апелювання до подій “Великої вітчизняної війни” (наприклад, відкриття каплиці на честь загиблих у боях за Савур-Могилу представників незаконних збройних формувань у рамках заходів, приурочених 74-й річниці визволення Донбасу від німецьких військ тощо).

\section{Висновки}

Таким чином сучасна російська воєнно-історична наука характеризується тенденційністю у підходах до оцінювання та інтерпретації важливих історичних подій, явищ. Поступово підпорядкувавшись політичному режиму, історична наука стала для російської влади інструментом вирішення воєнно-політичних завдань. Фальсифікація історії для маніпуляції суспільною свідомістю здійснюється на “науковій” 
платформі з метою спотворення історичної дійсності і спрямовується на мобілізацію та консолідацію населення Російської Федерації на підтримку зовнішньополітичного курсу держави, ідеологічне “обгрунтування" окупації Автономної Республіки Крим та прихованої збройної агресії на Сході України; масований вплив на населення тимчасово окупованих територій України із використанням історичного дискурсу, переважно періоду Другої світової війни. 3 огляду на це потребує посилення захист громадян України від негативних інформаційних впливів, протидії маніпуляціям суспільною свідомістю i поширенню недостовірної інформації, що має втілюватися через інститути освіти, культури, а також засоби масової комунікації.

\section{Бібліографія}

Means of Russia hybrid warfare against Ukraine: scientific edition - K.: National Defence University of Ukraine named after Ivan Cherniakhovskyi (2017), c. 40.

Аналітична доповідь до Щорічного Послання Президента України до Верховної Ради України «Про внутрішнє та зовнішнє становище України в 2018 році». - К.: НІСД (2018), с. 688.

Бабка В.Л. Історична пам'ять як фактор політичного впливу в незалежній Україні: дис. ... канд. політ. наук / 23.00.03 - політична культура та ідеологія // Володимир Леонідович Бабка; Ніжинський державний університет імені Миколи Гоголя. - Ніжин (2016), с. 249.

Вашкевич В.М. Історична свідомість студентської молоді: ціннісно-світоглядні орієнтири. Навчальний посібник для вищ. навч. закл. - К.: Світогляд (2010), c. 274.

Війна і міф. Невідома Друга світова / за заг. ред. О. Зінченка, В. В’ятровича, М. Майорова. - Харків: Книжковий клуб «Клуб Сімейного Дозвілля» (2016), c. 272.

Гібридна війна: in verbo et in praxi: монографія/Донецький національний університет імені Василя Стуса / під. заг. ред. проф. Р.О. Додонова. - Вінниця: ТОВ «Нілан-ЛТД» (2017), с. 412.

Историческое краеведение. Страницы истории Донбасса: новейшая и современная история (с 1939 года до современности). 11 класс: учебное пособие/ сост. Морозов П.Л., Пестрецов В.В. - В 2 ч. Ч.2 - Донецк: ГОУ ДПО «Донецкий РИДПО» (2019), с. 172. 
Историческое краеведение: Введение в историю Донецкого края. 5 класс: учебное пособие/Сост. Кожемяка О.Л., Морозов П.Л., Пестрецов В.В. - 3-е изд., дополн. и перераб. - Донецк: ГОУ ДПО «Донецкий РИДПО» (2019), с. 230.

Кара-Мурза С.Г. Манипуляция сознанием. - М.: Изд-во: Эксмо (2005), с. 832.

Кушниренко В.В., Ольховик Ю.И. Направления фальсификации отечественной военной истории и основные формы работы по её противодействию / В.В. Кушниренко, Ю.И. Ольховик // Гуманитарный вестник ВА РВСН, 2019, 2 (15), c. 133-141.

Островская И.В. История становления и развития русского и пророссийского движений Крыма и Севастополя в 1991 - марте 2014 гг.: автореф. дисс. ... канд. ист. наук / 07.00.02 - Отечественная история // Островская Инна Валериевна; Кубанский государственный университет. - Краснодар (2018), с. 33.

Політика історичної пам'яті в контексті національної безпеки України: аналіт. доповідь/ [Яблонський В.М., Лозовий В.С., Валевський О.Л., Здіорук С.І., Зубченко С.О. та ін.] / за заг. ред. В. М. Яблонського. - Київ: НІСД (2019), с. 144.

Постановление Правительства Российской Федерации № 1493. О государственной программе „Патриотическое воспитание граждан Российской Федерации на 2016-2020 годы” от 30.12.2015.

Россия против Истории. Наказание за пересмотр // Доклад Международной Агоры (2018), с. 19. [Электронный ресурс]. - Режим доступа: https://agora. legal/articles/Doklad-Mezhdunarodnoi-Agory-Rossiya-protiv-Istorii-Nakazanieza-peresmotr/13

Світова гібридна війна: український фронт: монографія / за заг. ред. В.П. Горбуліна. - К.: НІСД (2017), с. 496.

Сосновский Д.В. Процессы формирования региональной идентичности в Крыму в контексте поляризации украинского общества (1991-2014): автореф. дисс. ... канд. полит. наук / 23.00.04 - Политические проблемы международных отношений, глобального и регионального развития// Сосновский Дмитрий Викторович; Московский государственный университет имени М.В. Ломоносова. - М. (2014), с. 29.

Старченко Р.А. Языковая жизнь и этнополитические ориентации крымчан: 2013-2014 гг.: автореф. дисс. ... канд. ист. наук / 07.00.07 - Этнография, этнология и антропология // Старченко Роман Александрович; Институт этнологии и антропологии имени Н. Н. Миклухо-Маклая РАН. - М (2015), с. 38.

Трушин А.С. Из опыта работы общественно-государственной организации «Российское военно-историческое общество» / А.С. Трушин // Русский мир: 
проблемы духовно-нравственного, гражданско-патриотического воспитания и пути их решения: пленарные доклады Международной научно-практической конференции (Донецк, 24 октября 2018 г.). - Донецк: Изд-во ДонНУ (2018), с. 115-118.

Указ Президента Российской Федерации № 1666 „Стратегия государственной национальной политики Российской Федерации на период до 2025 года” от 19.12.2012.

Указ Президента Российской Федерации № 1710 О создании Общероссийской общественно-государственной организации „Российское военно-историческое общество” от 29.12.2012.

Федеральный закон № 128-Ф3 „О внесении изменений в отдельные законодательные акты Российской Федерации” от 05.05.2014.

Якубова Л. „Русский мир” в Україні: на краю прірви. - К.: ТОВ «Видавництво „КЛІО”» (2018), с. 384.

\section{References}

Analitychna dopovid' do Shchorichnoho Poslannya Prezydenta Ukrayiny do Verkhovnoyi Rady Ukrayiny «Pro vnutrishnye ta zovnishnye stanovyshche Ukrayiny v 2018 rotsi». - K.: NISD (2018), c. 688.

Babka V.L. Istorychna pa"yat' yak faktor politychnoho vplyvu v nezalezhniy Ukrayini: dys.... kand. polit. nauk / 23.00.03 - politychna kul'tura ta ideolohiya // Volodymyr Leonidovych Babka; Nizhyns'kyy derzhavnyy universytet imeni Mykoly Hoholya. - Nizhyn (2016), c. 249.

Federal'nyy zakon № 128-FZ „O vnesenii izmeneniy v otdel'nyye zakonodatel'nyye akty Rossiyskoy Federatsii” ot 05.05.2014.

Hibrydna viyna: in verbo et in praxi: monohrafiya / Donets'kyy natsional'nyy universytet imeni Vasylya Stusa / pid. zah. red. prof. R.O. Dodonova. - Vinnytsya: TOV «Nilan-LTD», 2017. - $412 \mathrm{~s}$.

Istoricheskoye krayevedeniye. Stranitsy istorii Donbassa: noveyshaya i sovremennaya istoriya (s 1939 goda do sovremennosti). 11 klass: uchebnoye posobiye / sost. Morozov P.L., Pestretsov V. V. - V 2 ch. CH.2 - Donetsk: GOU DPO «Donetskiy RIDPO» (2019), c. 172.

Istoricheskoye krayevedeniye: Vvedeniye $\mathrm{v}$ istoriyu Donetskogo kraya. 5 klass: uchebnoye posobiye / Sost. Kozhemyaka O.L., Morozov P.L., Pestretsov V.V. - 3-e izd., dopoln. i pererab. - Donetsk: GOU DPO «Donetskiy RIDPO» (2019), c. 230. 
Kara-Murza S.G. Manipulyatsiya soznaniyem. - M.: Izd-vo: Eksmo (2005), c. 832.

Kushnirenko V.V., Ol'khovikYU.I. Napravleniya fal'sifikatsii otechestvennoyvoyennoy istorii i osnovnyye formy raboty po eyë protivodeystviyu / V.V. Kushnirenko, YU.I. Ol'khovik // Gumanitarnyy vestnik VA RVSN. - 2019, 2 (15), c. 133-141.

Means of Russia hybrid warfare against Ukraine: scientific edition. - K.: National Defence University of Ukraine named after Ivan Cherniakhovskyi (2017), c. 40.

Ostrovskaya I.V. Istoriya stanovleniya i razvitiya russkogo i prorossiyskogo dvizheniy Kryma i Sevastopolya v 1991 - marte 2014 gg.: avtoref. diss. ... kand. ist. nauk / 07.00.02 - Otechestvennaya istoriya // Ostrovskaya Inna Valeriyevna; Kubanskiy gosudarstvennyy universitet. - Krasnodar (2018), c. 33.

Polityka istorychnoyi pa"yati v konteksti natsional'noyi bezpeky Ukrayiny: analit. dopovid' / [Yablons'kyy V.M., Lozovyy V. S., Valevs'kyy O.L., Zdioruk S.I., Zubchenko S.O. ta in.] / za zah. red. V. M. Yablons'koho. - Kyyiv: NISD (2019), c. 144.

Postanovleniye Pravitel'stva Rossiyskoy Federatsii № 1493 „O gosudarstvennoy programme „Patrioticheskoye vospitaniye grazhdan Rossiyskoy Federatsii na 2016-2020 gody" ot 30.12.2015.

Rossiya protiv Istorii. Nakazaniye za peresmotr // Doklad Mezhdunarodnoy Agory, 2018. - 19 s. [Elektronnyy resurs]. - Rezhim dostupa: https://agora.legal/ articles/Doklad-Mezhdunarodnoi-Agory-Rossiya-protiv-Istorii-Nakazanie-zaperesmotr/13.

Sosnovskiy D.V. Protsessy formirovaniya regional'noy identichnosti v Krymu v kontekste polyarizatsii ukrainskogo obshchestva (1991-2014): avtoref. diss.... kand. polit. nauk / 23.00.04 - Politicheskiye problemy mezhdunarodnykh otnosheniy, global'nogo i regional'nogo razvitiya // Sosnovskiy Dmitriy Viktorovich; Moskovskiy gosudarstvennyy universitet imeni M.V. Lomonosova. - M. (2014), c. 29.

Starchenko R.A. YAzykovaya zhizn' i etnopoliticheskiye oriyentatsii krymchan: 2013-2014 gg.: avtoref. diss. ... kand. ist. nauk / 07.00.07 - Etnografiya, etnologiya i antropologiya // Starchenko Roman Aleksandrovich; Institut etnologii i antropologii imeni N. N. Miklukho-Maklaya RAN. - M. (2015), c. 38.

Svitova hibrydna viyna: ukrayins'kyy front: monohrafiya / za zah. red. V. P. Horbulina. - K.: NISD (2017), c. 496.

Trushin A.S. Iz opyta raboty obshchestvenno-gosudarstvennoy organizatsii «Rossiyskoye voyenno-istoricheskoye obshchestvo» / A.S. Trushin // Russkiy mir: problemy dukhovno-nravstvennogo, grazhdansko-patrioticheskogo vospitaniya i puti ikh resheniya: plenarnyye doklady Mezhdunarodnoy nauchno-prakticheskoy konferentsii (Donetsk, 24 oktyabrya 2018 g.). - Donetsk: Izd-vo DonNU (2018), c. 115-118. 
Ukaz Prezidenta Rossiyskoy Federatsii № 1666 „Strategiya gosudarstvennoy natsional'noy politiki Rossiyskoy Federatsii na period do 2025 goda" ot 19.12.2012.

Ukaz Prezidenta Rossiyskoy Federatsii № 1710 O sozdanii Obshcherossiyskoy obshchestvenno-gosudarstvennoy organizatsii „Rossiyskoye voyenno-istoricheskoye obshchestvo" ot 29.12.2012.

Vashkevych V.M. Istorychna svidomist' student.s'koyi molodi: tsinnisno-svitohlyadni oriyentyry. Navchal'nyy posibnyk dlya vyshch. navch. zakl. - K.: Svitohlyad (2010), c. 274.

Viyna i mif. Nevidoma Druha svitova / za zah. red. O. Zinchenka, V. V”yatrovycha, M. Mayorova. - Kharkiv: Knyzhkovyy klub «Klub Simeynoho Dozvillya» (2016), c. 272.

Yakubova L. „Russkyy myr” v Ukrayini: na krayu prirvy. - K.: TOV «Vydavnytstvo „KLIO”» (2018), c. 384. 